\title{
Obstruktiv søvnapné
}

\section{Obstruktiv søvnapné er en meget sammensatt lidelse. Diagnostikk og patofysiologi varierer, mens behandlingstiltakene har vært mer ensartet - i form av kontinuerlig positivt luftveistrykk (CPAP) via en maske for å holde øvre luftveier åpne. En dypere forståelse av pato- fysiologien hos den enkelte vil kunne gi bedre tilpasset og mer effektiv behandling. Vi vil her oppsummere nyere kunnskap og mulige behand- lingsmessige konsekvenser.}

Diagnosen obstruktiv søvnapné stilles ofte først etter flere år med symptomer. Nattlige symptomer som snorking og pustestopp under søvn observeres som regel av pasientens sengepartner, mens redusert dagtidsfunksjon grunnet søvnighet eller utmattelse kan være hovedproblemet for pasienten. «Bare snorking» og uttalt obstruktiv søvnapné er ytterpunkter på en kontinuerlig skala for søvnrelaterte obstruktive respirasjonsforstyrrelser (1), men kvantitative snorkedata rapporteres sjelden etter en søvnundersøkelse.

Snorking er svært vanlig, men også noe vanskelig å kvantitere. Øvre luftveismotstandssyndrom (upper airway resistance syndrome, UARS) er en omdiskutert mellomtilstand som i 3. utgave av International Classification of Sleep Disorders er lagt inn under obstruktiv søvnapné (2).

\section{Patofysiologi}

Snorking

Muskelaktiviteten som i våken tilstand holder luftveiene åpne, reduseres under søvn. Dette bidrar til at snorking er svært vanlig. Derfor snorker de fleste med obstruktiv søvnapné, men langt fra alle som snorker har obstruktiv søvnapné.

Snorking synes ikke bare å være relatert til obstruktiv søvnapné, men bidrar også kausalt ved at nerven til luftveisdilatatorene skades (3) og ved ledsagende ødem i uvula (4).

\section{Fenotyper av obstruktiv søvnapné}

Obstruktiv søvnapné er en heterogen lidelse. Minst fire ulike faktorer synes å være sentrale: luftveienes lukkingstendens (faktor 1), respons fra musklene som åpner øvre luftveier (faktor 2), tidlig cerebral aktiveringstendens (arousal) ved episoder med redusert respirasjon (faktor 3), ustabil kontroll av ventilasjonen (faktor 4) (5).

For den enkelte pasient vil patogenesen som oftest være sammensatt, men inndeling i klinisk-fysiologiske undergrupper (fenotyping) kan være nyttig for å sortere ut hvilke mekanismer som er viktigst.

\section{Luftveienes lukkingsstendens} og muskelrespons

Luft suges inn i luftveiene som følge av at respirasjonsbevegelsene lager et undertrykk. Ved hvilket trykk øvre luftveier lukker seg $\left(p_{\text {crit }}\right)$, er sentralt. Luftveier som lukker seg ved positive, nøytrale eller lette negative trykk, er assosiert med alvorlig obstruktiv søvnapné (5). Hos dem med luftveier som først lukker seg ved trykk under $-2 \mathrm{~cm} \mathrm{H}_{2} \mathrm{O}$, vil faktor 2, faktor 3 og faktor 4 i større grad avgjøre fenotypen.

Å måle $p_{\text {crit }}$ og muskelrespons som uttrykk for luftveienes lukkingstendens er ressurskrevende. Et aktuelt alternativ ved behandlingsresistent obstruktiv søvnapné kan være endoskopi i lett narkose, hvor man observerer de øvre luftveienes form og diameter under pusting. For å opprettholde luftstrømmen gjennom trange partier må hastigheten opp. Da øker også undertrykket og tendensen til lukking av øvre luftveier (Bernoullis lov).

Menn har mer parafaryngealt bløtvev (fett, muskler), noe som gjør luftveiene trangere. Tonsillhypertrofi kan også medvirke til obstruktiv søvnapné (6). Barn som vokser opp som munnpustere, har trolig økt risiko for å få mindre kjever (7). Små kjever gjør at den ventrale øvre luftveisveggen forskyves bakover slik at passasjen blir trangere. I tillegg bidrar munnpusting trolig til sykdommens alvorlighetsgrad (1).

\section{Aktiveringsterskel og overventilasjon}

En «aktivering» (arousal) er en kortvarig sentralnervøs kortikal aktivering uten atferdsmessig oppvåkning og er definert fenomenologisk av American Academy of Sleep Medicine (AASM) som en plutselig frekvensøkning i EEG av mer enn tre sekunders varighet (8). Aktivering kan forekomme uten erkjennbar årsak eller være assosiert med episoder med redusert respirasjon og kan brukes som et mål på «søvnfragmentering».

Hos voksne er aktiveringsevnen under søvn antakelig mindre avgjørende for å kunne gjenoppta normal respirasjon etter apné (stopp i respirasjonen) eller hypopné

\author{
Morten Engstrøm \\ morten.engstrom@ntnu.no \\ Avdeling for nevrologi og klinisk nevrofysiologi \\ St. Olavs hospital \\ og \\ Institutt for nevromedisin \\ Det medisinske fakultet \\ Norges teknisk-naturvitenskapelige universitet \\ Kornelia Katalin Beiske \\ Nevroklinikken \\ Seksjon for klinisk nevrofysiologi \\ Akershus universitetssykehus \\ Harald Hrubos-Strøm \\ $\emptyset$ re-nese-hals-avdelingen \\ Kirurgisk divisjon \\ Akershus universitetssykehus \\ Sigurd Aarrestad \\ Lungemedisinsk avdeling \\ Oslo universitetssykehus, Ullevål \\ og \\ Nasjonal kompetansetjeneste \\ for hjemmerespirator \\ Haukeland universitetssykehus \\ Trond Sand \\ Avdeling for nevrologi og klinisk nevrofysiologi \\ St. Olavs hospital \\ Institutt for nevromedisin \\ Det medisinske fakultet \\ Norges teknisk-naturvitenskapelige universitet
}

\section{HOVEDBUDSKAP}

Obstruktiv søvnapné er en heterogen tilstand

$\emptyset$ kt kunnskap om tilstandens patofysiologi kan gi bedre diagnostikk og behandling 
(redusert respirasjon) fordi mange respiratoriske episoder hos voksne avsluttes før eller uten erkjennbar aktivering (5). Aktivering som starter før episoden med redusert respirasjon er avsluttet, antyder sterk aktiveringstendens og økt tendens til «søvnfragmentering» som følge av respirasjonsforstyrrelsen (5). Overdreven ventilasjon etter en respiratorisk episode (overventilasjonsrespons) kan gi hypokapni og forbigående redusert respirasjon. Varierende respirasjon kan disponere for nye episoder med luftveislukking.

En sterk aktiveringstendens kan synes å være relatert til overventilasjonsrespons (5). Men ikke alle måter å redusere aktiveringstendensen på har nødvendigvis gunstig effekt. Aktiveringsterskelen er lavest når man er utsovet og stiger når man er i underskudd på søvn (9). Både søvndeprivasjon som følge av søvnfragmentering og for kort kontinuerlig søvn kan forverre respirasjonsproblemer under søvn (10).

\section{Behandling}

Ved obstruktiv søvnapné relatert til overvekt har vektreduksjon gunstig effekt (11). Regelmessig fysisk trening kan også motvirke tilstanden (12). Råd om å holde seg slank og i form kan man gi uten en søvnundersøkelse, men påvisning av betydelig respirasjonsvariasjon kan motivere til livsstilsendring og vektreduksjon hos enkelte pasienter. Å unngå ryggleie under søvn er en enkel posisjonsterapi som trolig brukes for lite ved stillingsrelatert obstruktiv søvnapné (13).

I tillegg til vektreduksjon vil behandling med søvnapnéskinne (som presser underkjeven fremover) og kontinuerlig positivt luftveistrykk (CPAP) motvirke kollaps av luftveiene. Bedre forståelse av patofysiologien er en forutsetning for god individualisert terapi. Ved CPAP-behandling er det vist at bruk av munn-nese-maske gir økt tendens til øvre luftveiskollaps og behov for høyere trykk enn bruk av nesemaske (14). For pasienter med sterk tendens til luftveissammenfall kan munn-nese-maske derfor være ugunstig. Sterk aktiveringstendens kan være upåvirket av CPAP-behandling (15). Utvikling av og mulighet for valg av algoritmer for auto-CPAP-behandling basert på patofysiologiske fenotyper vil kunne gi bedre behandling per se og bedre mestring/etterlevelse hos pasientene.

Det er forsøkt spesifikk trening av muskulaturen som åpner øvre luftveier (16) og elektrisk stimulering av dilatatormusklene (17). Begge deler kan være behandlingsalternativer ved dårlig muskelrespons fra luftveisdilatatorer.

Kan aktiveringstendensen endres med medikamentell behandling? En dobbeltblindet, randomisert overkrysningsstudie har vist effekt av en dose ezopiklon på antall respiratoriske episoder under søvn hos pa-
Tabell 1 Mulige terapeutiske konsekvenser av fenotyping ved obstruktiv søvnapné. CPAP = kontinuerlig positivt luftveistrykk

$\begin{array}{ll}\text { Øvre luftveier som lett lukker seg } & \begin{array}{l}\text { Unngå munn-nese-maske ved CPAP-behandling } \\ \text { Unngå ryggleie } \\ \text { Søvnapnéskinne } \\ \text { Ganeplastikk } \\ \text { Tilpasset auto-CPAP-algoritme }\end{array} \\ \begin{array}{ll}\text { Elektrisk muskelstimulator } \\ \text { som skal åpne øvre luftveier }\end{array} & \begin{array}{l}\text { Spesifikk trening av muskulatur i øvre luftveier } \\ \text { Tilpasset auto-CPAP-algoritme }\end{array} \\ \begin{array}{ll}\text { Lav terskel for cerebral aktivering } \\ \text { ved redusert respirasjon }\end{array} & \begin{array}{l}\text { Aktiveringsdempende medikasjon } \\ \text { Tilpasset auto-CPAP-algoritme }\end{array} \\ \text { Overventilasjonsrespons etter periode } & \text { Aktiveringsdempende medikasjon } \\ \text { med redusert respirasjon } & \text { Acetazolamid } \\ & \text { Oksygenterapi } \\ & \text { Tilpasset auto-CPAP-algoritme } \\ & \\ & \end{array}$

sienter med lav aktiveringsterskel, uten å forlenge de respiratoriske episodene eller øke desaturasjonstendensen (15). Muligheten for å behandle obstruktiv søvnapné med hypnotika gjelder antakelig bare selekterte grupper, og kunnskapsgrunnlaget virker foreløpig for tynt. Videre er det vist at oksygenbehandling (18) og acetazolamid (19) kan redusere tendensen til overventilasjonsrespons.

Det er også nylig publisert studier som viser nytteverdi av klinisk fenotyping ved vurdering av søvnapnéskinner (20) og ganeplastikk (21). Behandlingsmuligheter ved ulike fenotyper av obstruktiv søvnapné er oppsummert i tabell 1.

\section{Konklusjon}

Inndeling av pasienter med obstruktiv søvnapné i klinisk-fysiologiske undergrupper vil kunne gi mulighet til å skreddersy behandlingen i større grad enn det som gjøres i dag. Den vil antakelig best kunne justeres der en patofysiologisk mekanisme dominerer, mens mange pasienter antakelig vil ha en blanding av flere fenotypiske trekk. Mer forskning er nødvendig før vi kan få full nytte av individuelt tilpasset behandling $\mathrm{i}$ den praktiske, kliniske hverdagen.

En sunn livsstil med regelmessig mosjon og søvn, unngåelse av overvekt og redusert soving i ryggleie hos voksne er de enkleste og mest grunnleggende behandlingsrådene for å unngå obstruktiv søvnapné på befolkningsnivå.

\section{Morten Engstrøm (f. 1967)}

er overlege og førsteamanuensis. Han er sekretær i styret i Norsk forening for søvnmedisin og søvnforskning.

Forfatter har fylt ut ICMJE-skjemaet og oppgir ingen interessekonflikter.

\section{Kornelia Katalin Beiske (f. 1978)}

er overlege og ph.d.-kandidat.

Forfatter har fylt ut ICMJE-skjemaet og oppgir ingen interessekonflikter.

\section{Harald Hrubos-Strøm (f. 1975)}

er ph.d. og lege i spesialisering. Han er kasserer i styret i Norsk forening for søvnmedisin og søvnforskning og ansvarlig lege ved Oslo

Forfatter har fylt ut ICMJE-skjemaet og oppgir følgende interessekonflikter: Han er eier av Somnify.no, et nettbasert søvnterapiprogram.

\section{Sigurd Aarrestad (f. 1965)}

er overlege, regional koordinator for langtids mekanisk ventilasjon Helse Sør-Øst, leder av Nasjonal kompetansetjeneste for hjemmerespirator og nestleder i Norsk forening for søvnmedisin og søvnforskning.

Forfatter har fylt ut ICMJE-skjemaet og oppgir ingen interessekonflikter.

\section{Trond Sand (f. 1952)}

er seksjonsoverlege og professor

Forfatter har fylt ut ICMJE-skjemaet og oppgir ingen interessekonflikter.

\section{Litteratur}

1. Meen EK, Chandra RK. The role of the nose in sleep-disordered breathing. Am J Rhinol Allergy 2013; 27: 213-20

2. Sateia MJ. International classification of sleep disorders-third edition: highlights and modifications. Chest 2014; 146: 1387-94.

3. Poothrikovil RP, Al Abri MA. Snoring-induced nerve lesions in the upper airway. Sultan Qaboos Univ Med J 2012: 12: 161-8.

4. Alcoceba E, Gonzalez M, Gaig P et al. Edema of the uvula: etiology, risk factors, diagnosis, and treatment. J Investig Allergol Clin Immunol 2010; 20: $80-3$

5. Eckert DJ, White DP, Jordan AS et al. Defining phenotypic causes of obstructive sleep apnea. J Respir Crit Care Med 2013; 188: 996-1004. Søvnsenter og www.Somnify.no. Identification of novel therapeutic targets. Am 
6. Sólyom R, Csiszér I, Neagoş A. Tonsillar hypertrophy implications in sleep disorders in adults and children. Rom J Morphol Embryol 2014; 55 (suppl): 603-6.

7. Chung Leng Muñoz I, Beltri Orta P. Comparison of cephalometric patterns in mouth breathing and nose breathing children. Int J Pediatr Otorhinolaryngol 2014; 78: 1167-72.

8. Berry RB, Brooks R, Gamaldo CE et al. The AASM manual for the Scoring of Sleep and Associated Events: Rules, Terminology and Technical Specifications. Version 2.0. Darien, IL: American Academy of Sleep Medicine, 2012.

9. Eckert DJ, Younes MK. Arousal from sleep: implications for obstructive sleep apnea pathogenesis and treatment. J Appl Physiol (1985) 2014; 116: 302-13.

10. Bonnet MH, Doghramji K, Roehrs T et al. The scoring of arousal in sleep: reliability, validity, and alternatives. J Clin Sleep Med 2007; 3: 133-45.

11. Tuomilehto H, Seppä J, Uusitupa M. Obesity and obstructive sleep apnea-clinical significance of weight loss. Sleep Med Rev 2013; 17: 321 -9.

12. Verwimp J, Ameye L, Bruyneel M. Correlation between sleep parameters, physical activity and quality of life in somnolent moderate to severe obstructive sleep apnea adult patients. Sleep Breath 2013; 17: 1039-46.

13. Ravesloot MJ, van Maanen JP, Dun L et al. The undervalued potential of positional therapy in position-dependent snoring and obstructive sleep apnea-a review of the literature. Sleep Breath 2013; 17: 39-49.

14. Bettinzoli M, Taranto-Montemurro L, Messineo L et al. Oronasal masks require higher levels of positive airway pressure than nasal masks to treat obstructive sleep apnea. Sleep Breath 2014; 18 : 845-9.

15. Eckert DJ, Owens RL, Kehlmann GB et al. Eszopiclone increases the respiratory arousal threshold and lowers the apnoea/hypopnoea index in obstructive sleep apnoea patients with a low arousal threshold. Clin Sci (Lond) 2011; 120: 505-14.

16. Guimarães KC, Drager LF, Genta PR et al. Effects of oropharyngeal exercises on patients with moderate obstructive sleep apnea syndrome. Am J Respir Crit Care Med 2009; 179: 962-6.

17. Pengo MF. Steier J. Emerging technology: electrical stimulation in obstructive sleep apnoea. J Thorac Dis 2015; 7: 1286-97.

18. Wellman A, Malhotra A, Jordan AS et al. Effect of oxygen in obstructive sleep apnea: role of loop gain. Respir Physiol Neurobiol 2008; 162: 144-51.

19. Edwards BA, Sands SA, Eckert DJ et al. Acetazolamide improves loop gain but not the other physiological traits causing obstructive sleep apnoea. J Physiol 2012; 590: 1199-211.

20. Vecchierini MF, Attali V, Collet JM et al. A custommade mandibular repositioning device for obstructive sleep apnoea-hypopnoea syndrome: the ORCADES study. Sleep Med 2015. E-publisert 29.6.

21. Browaldh N, Nerfeldt P. Lysdahl M et al. SKUP3 randomised controlled trial: polysomnographic results after uvulopalatopharyngoplasty in selected patients with obstructive sleep apnoea. Thorax 2013; 68: 846-53

Mottatt 23.3. 2015, første revisjon innsendt 29.6.

2015, godkjent 14.10. 2015. Redaktør: Sigurd Høye. 